of anti-D will be required. Transplacental bleeding of $50 \mathrm{ml}$. or more occurred in 3 out of 740 cases in our series; the frequency, however, of such large foetomaternal transfusions is generally supposed to be lower. Thus Schneider and Schoof (1964), in a series of 1,300 hospital deliveries, observed no transplacental bleeds of more than $12 \mathrm{ml}$. We feel, therefore, that there is no justification in trying to adjust the standard dose of anti-D to the requirement met with in the rare instances of massive transplacental bleeding. In view of the limited supply of anti-D immunoglobulin the standard dose should be the smallest dose that is effective in cases with small and moderately large bleeds. In this context it is encouraging to note that in our study none of the six women in the treated group with bleeds of 5 to $25 \mathrm{ml}$. developed rhesus antibodies.

It therefore seems reasonable to propose that further trials be undertaken to determine whether, in fact, anti- $\mathrm{D}$ immunoprophylaxis may be achieved with doses even smaller than $250 \mu \mathrm{g}$.

We are indebted to Dr. W. Huitema, Kweekschool voor Vroedvrouwen, Amsterdam; Professor J. Janssens, Academisch Ziekenhuis V.U., Amsterdam; Professor L. A. Joosse, Academisch Ziekenhuis, Groningen ; Professor G. J. Kloosterman, Wilhelmina Gasthuis, Amsterdam ; Professor J. L. Mastboom, St. Radboud Ziekenhuis, Nijmegen ; Professor W. P. Plate, Academisch Ziekenhuis, Utrecht ; Dr. H. Rottinghuis, Onze Lieve Vrouwen Gasthuis,
Amsterdam; Professor A. L. C. Schmidt, Dijkzigt Ziekenhuis, Rotterdam; Dr. J. C. Seelen, Ziekenhuis van de H. Joannes de Deo, Den Haag; Professor A. Sikkel, Academisch Ziekenhuis, Leiden; and their respective staffs for participation in the trial.

The immunoglobulin preparation was produced by $\mathrm{Dr}$. H. W. Krijnen, Central Laboratory of the Blood Transfusion Service of the Netherlands Red Cross, Amsterdam.

The anti-D content of the immunoglobulin preparation was kindly determined by Dr. N. C. Hughes-Jones, Wright-Fleming Institute of Microbiology, St. Mary's Hospital, London. All serological tests were performed by Miss Josée Matthey.

\section{REFERENCES}

Ascari, W. Q., Allen, A. E., Baker, W. J., and Pollack, W. (1968). F. Amer. med. Ass., 205, 1 .

Chown, B. (1968). Lancet, 1, 759.

Clarke, C. A. (1967). Brit. med. $\dot{f}_{\text {. }}, 4,7$.

Combined Study (1966). Brit. med. F., 2, 907.

Dudok de Wit, C., and Borst-Eilers, E. '(1968). Brit. med. F., 1, 152.

Freda, V. J., Gorman, J. G., Pollack, W., Robertson, J. G., Jennings, E. R., and Sullivan, J. F. (1967). F. Amer. med. Ass., 199, 390.

Hughes-Jones, N. C., and Mollison, P. L. (1968). Brit. med. F., 1, 150.

Kleihauer, E., Braun, H., and Betke, K. (1957). Klin. W schr., 35, 637.

Nevanlinna, H. R., and Vainio, T. (1962). Proceedings of Eighth Congress of International Society of Blood Transfusion, Tokyo 1960, edited by L. Holländer, p. 281. Basel.

Schneider, J., and Schoof, G. (1964). Zbl. Gynäk., 86, 1829.

Woodrow, J." C., Bowley, C. C., Gilliver, B. E., and Strong, S. J. (1968). Brit. med. F., 1, 148 .

Zipursky, A., and Israels, L. G. (1967). Canad. med. Ass. 7., 97, 1245.

\title{
Significance of Rh-sensitization during Pregnancy: Its Relation to a Preventive Programme
}

\author{
JOHN C. GODEL,* M.D., F.R.C.P.(C.) ; DONALD I. BUCHANAN,* M.D., D.P.H.; JEAN M. JAROSCH,* R.T. \\ MAUREEN MCHUGH, $\dagger$ A.R.T.
}

Brit. med. F., 1968, 4, 479-482

\begin{abstract}
Cummary : A study of the incidence of $\mathbf{R h}$-sensitization $\$$ showed a $6.5 \%$ incidence of anti-D appearing for the first time during the last trimester of pregnancy. In 24 of the 29 subjects these antibodies were weak, and were found only when a sensitive technique using enzymetreated Rh-deletion test cells was employed. The remaining five, however, had high-titre antibodies, which were associated with a positive Coombs test on cord blood.

Rh-immune globulin administered at delivery resulted in disappearance of the anti-D in all but one of the subjects with weak antibody to whom it was given, suggesting that this treatment can reverse early sensitization. There was no effect when $\mathbf{R h}$-immune globulin was given to one subject with a high anti-D titre.

Since senisitization has been found to occur frequently during the last trimester of pregnancy, an antenatal schedule of prophylaxis is advocated.
\end{abstract}

\section{Introduction}

It is now generally accepted that the administration of $\mathrm{Rh}$-immune globulin to susceptible mothers at delivery may result in almost complete suppression of antibody formation in

\footnotetext{
* Hematology Research Unit, University of Alberta Hospital, Edmonton,

† Alberta.
}

the postpartum period (Brit. med. F., 1966 ; Freda, Gorman, and Pollack, 1966 ; Zipursky and Israels, 1967 ; Mollison, 1968).

Investigation into the prevention of $\mathrm{Rh}$ sensitization has been carried on in Edmonton since January 1967 as part of a co-operative study involving the western Canadian provinces (Canad. med. Ass. 7., 1967 ; Chown, 1967). Our part in the study was designed primarily to compare the effectiveness of two different doses of $\mathrm{Rh}$-immune globulin and to try to establish a minimum effective dose. However, we were also interested in trying to establish the incidence of sensitization during the last trimester of pregnancy. Our interest was stimulated by the fact that in northern Alberta from 1965 to $19673.5 \%$ of women with anti-D agglutinins found in the last trimester of pregnancy were primigravidae.

\section{Methods and Materials}

\section{Selection of Subjects}

Criteria for entry into the study were: (a) Rh-negative mother of any parity with an Rh-positive husband; $(b)$ no anti-D when first tested during pregnancy ; and (c) delivery of an $\mathrm{Rh}$-positive $\mathrm{ABO}$-compatible infant.

The following tests were done on all of the possible candidates for the study: $\mathrm{ABO}$ and $\mathrm{Rh}$ phenotype of the mother, $\mathrm{ABO}$ 
and $\mathrm{Rh}$ phenotype of the father (if his specimen was available), $\mathrm{ABO}$ and $\mathrm{Rh}$ phenotype and direct Coombs test on the baby.

Of 1,001 mothers considered 504 were excluded because they subsequently delivered $\mathrm{Rh}$-negative or $\mathrm{ABO}$-incompatible infants. Of the 497 - subjects eligible for the study 53 refused to participate, leaving a study group of 444 (see Table I).

TABLE I.-Selection of Study Group

\begin{tabular}{|c|c|c|c|c|}
\hline $\begin{array}{l}\text { Ineligible for treatment } \\
\text { Baby Rh-negative } \\
\text { Baby ABO incompatible }\end{array}$ & $\begin{array}{l}\cdots \\
\cdots\end{array}$ & $\begin{array}{l}\cdots \\
\cdots\end{array}$ & $\begin{array}{l}310 \\
194\end{array}$ & 504 \\
\hline 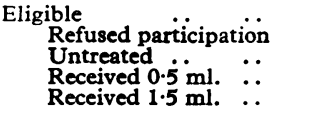 & $\begin{array}{l}\because \\
\because \\
\therefore\end{array}$ & 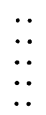 & $\begin{array}{r}53 \\
83 \\
178 \\
183\end{array}$ & 497 \\
\hline
\end{tabular}

\section{Study Group}

Of the 444 in the study 361 were treated and 83 were untreated (see Table I). The treated cases received an injection of either $0.5 \mathrm{ml}$. (145 $\mu \mathrm{g}$. anti-D) or $1.5 \mathrm{ml}$. (435 $\mu \mathrm{g}$. anti-D) of $\mathrm{Rh}$-immune globulin* within 48 hours after delivery. These were given in an alternate fashion in an attempt to establish a minimal effective dose. Gorman's data, as quoted by Zipursky and Israels (1967), suggests that the minimum effective dose may be less than $100 \mu \mathrm{g}$. of anti-D.

Seventy of the 83 untreated subjects were delivered before the availability of $\mathrm{Rh}$-immune globulin and were included as untreated controls. The remaining 13 included nine who objected to the injections but agreed to appear for follow-up blood tests at six weeks and six months. The other four were found at delivery to have titres of anti-D varying from $1: 8$ to $1: 64$, and produced infants with positive direct Coombs tests on cord blood. These subjects were not treated but were retained for further study.

\section{Antibody-testing}

The sera of the mothers included in the study were tested (a) at delivery, (b) 48 hours after delivery, (c) six weeks after delivery, and $(d)$ six months after delivery.

These sera were tested with the following known cells: (1) $O, R_{1} R_{2}$ cells pretreated with $1 \%$ ficin; (2) $O, R_{1} R_{2}$ cells pretreated with $0.1 \%$ protease $G$; (3) $\mathrm{O}, \mathrm{D}--/ \mathrm{D}-$ - cells pretreated with $1 \%$ ficin ; (4) O, D- - / D - cells pretreated with $0.1 \%$ protease $G$ (Buchanan, 1956; Buchanan and Dierich, 1965); and (5) O, D- - D- untreated cells (indirect antiglobulin test using an anti-IgG serum). In every case the ficin- or protease-G-treated test cells gave the best evidence of early sensitization, and probably all but one case would have been missed if reliance had been placed solely on a saline or albumin indirect antiglobulin test as the main screening procedure.

\section{Antibodies at Delivery}

An unexpected finding was that 29 of the 444 subjects, previously negative, were found to have anti-D at delivery. Table II shows a breakdown of these cases with regard to the pregnancy in which the antibodies occurred. The proportion of subjects showing sensitization was between 5 and $6 \%$ for the first three pregnancies-almost identical with the overall figure of $6.5 \%$. It has been generally assumed that the risk of antibody formation is less in the first pregnancy than in any subsequent one. Though our figures are based on small numbers, they suggest that the risk may be as great in the first pregnancy as in the second or third.

* $16 \%$ gammaglobulin, $290 \mu \mathrm{g}$. of anti- $/ \mathrm{ml}$. Lot 4-Connaught Laboratories, Toronto.
TABLB II.-Pregnancy in Which Antibodies Were First Detected

\begin{tabular}{c|c|c|c} 
Gravida & $\begin{array}{c}\text { No. with } \\
\text { Antibodies }\end{array}$ & $\begin{array}{c}\text { No. in } \\
\text { Study Group }\end{array}$ & $\%$ \\
\hline I & 10 & 179 & $5 \cdot 6$ \\
II & 6 & 119 & $5 \cdot 0$ \\
III & 4 & 67 & $5 \cdot 9$ \\
IV & 7 & 48 & $14 \cdot 6$ \\
VII & 2 & 13 & $15 \cdot 4$ \\
VII & 0 & 11 & 0 \\
VIII & 0 & 4 & 0 \\
IX & 0 & 0 & 0 \\
X & 0 & 2 & 0 \\
\hline Total & 0 & 1 & $6 \cdot 5$ \\
\hline
\end{tabular}

Details of these cases are given in Tables III and IV. The subjects in Table III were untreated, while those in Table IV were treated within 48 hours after delivery with either 0.5 or $1.5 \mathrm{ml}$. of Rh-immune globulin. Four of the untreated group and one of the treated group had antibody titres with ficinand protease-G-treated cells of from $1: 8$ to $1: 64$ when tested at delivery. Their infants showed weak but definite positive direct Coombs tests on cord blood. The others had weak antibodies at delivery, detected only with the enzyme-treated deletion cells.

TABLB III.-Subjects with Antibody at Delivery-Follow-up of the Untreated Group

\begin{tabular}{|c|c|c|c|c|c|c|}
\hline \multirow{3}{*}{$\begin{array}{l}\text { Case } \\
\text { No. }\end{array}$} & \multirow{3}{*}{ Gravida } & \multicolumn{5}{|c|}{ Antibody Testing } \\
\hline & & \multicolumn{2}{|c|}{ Antenatal } & \multicolumn{3}{|c|}{ Postnatal } \\
\hline & & Gest. (wks) & Result & Delivery & 6 Weeks & 6 Months \\
\hline \begin{tabular}{r|}
1 \\
2 \\
3 \\
4 \\
5 \\
6 \\
7 \\
8 \\
9 \\
10 \\
11 \\
12 \\
13
\end{tabular} & $\begin{array}{l}2 \\
4 \\
3 \\
3 \\
2 \\
1 \\
2 \\
4 \\
1 \\
6 \\
1 \\
4 \\
4\end{array}$ & $\begin{array}{l}33 \\
33 \\
28 \\
32 \\
36 \\
33 \\
38 \\
38 \\
36 \\
35^{*} \\
39 \\
31 \\
39\end{array}$ & $\begin{array}{l}\text { Neg. } \\
\text { Neg. } \\
\text { Neg. } \\
\text { Neg. } \\
\text { Neg. } \\
\text { Neg. } \\
\text { Neg. } \\
\text { Neg. } \\
\text { Neg. } \\
\text { Neg. } \\
\text { Neg. } \\
\text { Neg. } \\
\text { Neg. }\end{array}$ & $\begin{array}{c}1: 8 \\
1: 64 \\
1: 16 \\
1: 16 \\
1: 16 \\
+ \\
+++ \\
++ \\
+ \\
++ \\
+ \\
\mathbb{W} \\
\mathbb{W}\end{array}$ & $\begin{array}{c}\bar{z} \\
\bar{z} \\
1: 64 \\
\text { Neg. } \\
++ \\
\text { Neg. } \\
+ \\
\mathbb{W} \\
1: 4 \\
\text { Neg. } \\
\overline{1}: 4\end{array}$ & $\begin{array}{c}1: 64 \\
1: 2048 \\
1: 64 \\
- \\
\text { Neg. } \\
+ \\
1: 8 \\
\text { Neg. } \\
1: 2 \\
W \\
\text { Neg. } \\
\text { Neg. } \\
1: 2\end{array}$ \\
\hline
\end{tabular}

TABLB IV.-Subjects with Antibody Found at Delivery-Follow-up of Treatment

\begin{tabular}{|c|c|c|c|c|c|c|c|}
\hline \multirow{3}{*}{$\begin{array}{l}\text { Case } \\
\text { No. }\end{array}$} & \multirow{3}{*}{ Gravida } & \multicolumn{5}{|c|}{ Antibody-testing } & \multirow{3}{*}{$\begin{array}{c}\text { Rh } \\
\text { Immune } \\
\text { Globulin } \\
\text { Dose } \\
(\mathrm{ml} .) \neq \\
\end{array}$} \\
\hline & & \multicolumn{2}{|c|}{ Antenatal } & \multicolumn{3}{|c|}{ Postnatal } & \\
\hline & & Gest. (wks) & Result & Delivery & 6 Weeks & 6 Months & \\
\hline $\begin{array}{l}14 \\
15 \\
16 \\
17 \\
18 \\
19 \\
20 \\
21 \\
22 \\
23 \\
24 \\
25 \\
26 \\
27\end{array}$ & $\begin{array}{l}3 \\
2 \\
1 \\
4 \\
1 \\
1 \\
4 \\
1 \\
3 \\
1 \\
4 \\
2 \\
1 \\
1\end{array}$ & $\begin{array}{l}33 \\
36 \\
39 \\
36 \\
36 \\
35 \\
34 * \\
39 \\
37 \\
37 \\
34 \\
36 \\
24 \\
36\end{array}$ & $\begin{array}{l}\text { Neg. } \\
\text { Neg. } \\
\text { Neg. } \\
\text { Neg. } \\
\text { Neg. } \\
\text { Neg. } \\
\text { Neg. } \\
\text { Neg. } \\
\text { Neg. } \\
\text { Neg. } \\
\text { Neg. } \\
\text { Neg. } \\
\text { Neg. } \\
\text { Neg. }\end{array}$ & 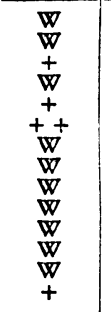 & $\begin{array}{c}+ \\
+ \\
1: 1 \\
++ \\
+ \\
+ \\
\pm \\
1: 2 \\
1: 128 \\
1: 2 \\
1: 1 \\
1: 8\end{array}$ & $\begin{array}{c}\text { Neg. } \\
\text { Neg. } \\
\text { Neg. } \\
\text { Neg. } \\
\text { Neg. } \\
\text { Neg. } \\
\text { Neg. } \\
\text { Neg. } \\
\text { :- } \\
1: 256 \\
\text { Neg. } \\
\text { Neg. } \\
\text { Neg. } \\
+\end{array}$ & $\begin{array}{l}0.5 \\
0.5 \\
1.5 \\
0.5 \\
1.5 \\
1.5 \\
1.5 \\
0.5 \\
1.5 \\
0.5 \\
1.5 \\
1.5 \\
0.5 \\
0.5\end{array}$ \\
\hline $\begin{array}{l}28 \\
29\end{array}$ & $\begin{array}{l}2 \\
5\end{array}$ & $\begin{array}{l}35 \\
29+\end{array}$ & $\begin{array}{l}\text { Neg. } \\
\text { Neg. }\end{array}$ & $1: 32$ & $1: 128$ & $1: 256$ & $\begin{array}{l}.52 \mathrm{w}) \\
0.5 \\
0.5\end{array}$ \\
\hline
\end{tabular}

\section{Results of Treatment}

\section{Subjects Negative for Antibody at Delivery}

Table $\mathrm{V}$ shows the results of follow-up in the group without detectable antibodies at delivery. Seventy subjects were untreated. Forty-two of these were followed to six months, and two $(4.8 \%)$ were found to have detectable antibodies. These antibodies were not strong, being recorded as positive only in the first tube of the titration with the enzyme-treated D- - /D - cells ; nevertheless, they had anti-D specificity. 
TABLE V.-Follow-up-Subjects with No Antibodies at Delivery

\begin{tabular}{|c|c|c|c|c|c|c|c|}
\hline & & & \multirow{2}{*}{ No. } & \multicolumn{4}{|c|}{ Six-month Follow-up } \\
\hline & & & & No. & Pos. & Neg. & $\%$ Pos. \\
\hline $\begin{array}{l}\text { Treated } \\
0.5 \mathrm{ml} . \\
1.5 \mathrm{ml} . \\
\text { Untreated }\end{array}$ & $\begin{array}{l}. . \\
\because \\
\cdots\end{array}$ & $\begin{array}{l}\ddot{ } \\
\cdots \\
\cdots\end{array}$ & $\begin{array}{r}345 \\
169 \\
176 \\
70\end{array}$ & $\begin{array}{r}118 \\
65 \\
53 \\
42\end{array}$ & $\begin{array}{l}0 \\
0 \\
2\end{array}$ & $\begin{array}{l}65 \\
53 \\
40\end{array}$ & $\begin{array}{l}0.0 \\
0.0 \\
4.8\end{array}$ \\
\hline
\end{tabular}

A total of 345 subjects were treated with either $0.5 \mathrm{ml}$. or $1.5 \mathrm{ml}$. of $\mathrm{Rh}$-immune globulin $(290 \mu \mathrm{g}$. anti-D/ml.). None of the 118 followed to six months developed anti-D. In subjects in whom no antibody could be detected at delivery the minimal dose of $0.5 \mathrm{ml}$. (145 $\mu \mathrm{g}$. anti-D) appeared to be as effective as $1.5 \mathrm{ml}$. (435 $\mu \mathrm{g}$. anti-D) in suppressing subsequent antibody formation.

\section{Subjects Positive for Antibody at Delivery}

Twenty-nine subjects showed antibody at the time of delivery (Table II). Thirteen were untreated (Table III), and 16 were treated (Table IV).

Four of the cases showing strong antibody were in the untreated group and at six months had a persistence of high antibody levels. The fifth case (No. 28) was treated with $0.5 \mathrm{ml}$. of Rh-immune globulin and has not yet been followed to six months. At six weeks, however, she had an antibody titre of $1: 128$, a level much higher than would be expected from the administration of $0.5 \mathrm{ml}$. of passive antibody alone, and at six months the titre is $1: 256$.

Table VI summarizes the follow-up of the 24 subjects in whom a weak antibody was found at delivery. Nine were untreated and five of these $(55.6 \%)$ had detectable anti-D when tested six months later. Thirteen were treated with $\mathrm{Rh}$-immune globulin, and six months later only one (7.7\%) (Case 23 ) was found to have developed anti-D.

TABLE VI.-Weak Antibodies at Delivery Follow-up

\begin{tabular}{cc|c|c|c|c} 
& & & \multicolumn{2}{|c}{ Positive at 6 Months } \\
\hline & No. & No. & $\%$ \\
\hline $\begin{array}{l}\text { Treated } \\
\text { Untreated }\end{array}$ & $\cdots$ & 15 & $1 / 13$ & $7 \cdot 7$ \\
\hline & 9 & $5 / 9$ & 55.6 \\
\hline
\end{tabular}

Several facts about Case 23 are significant. Firstly, she was primigravid ; secondly, she had a very weak anti-D at delivery, detected only with enzyme-treated $\mathrm{D}-1 \mathrm{D}-\mathrm{C}-\mathrm{cells}$, but not with a saline indirect Coombs test ; thirdly, she was treated with only $0.5 \mathrm{ml}$. (145 $\mu \mathrm{g}$. anti-D) of Rh-immune globulin.

\section{Effects of Rh-immune Globulin}

Anti-D was detected within 48 hours of the administration of $\mathrm{Rh}$-immune globulin and was still detectable six weeks later, with the level of anti-D varying from a weak plus following $0.5 \mathrm{ml}$. to a titre of $1: 8$ following the $1.5 \mathrm{ml}$. dose. Passive anti-D was undetectable at six months.

No side-effects to the intramuscular administration of $\mathbf{R h}$ immune globulin have been found in the 361 subjects to whom treatment has been given.

\section{Discussion}

\section{Sensitization Occurring During the Last Trimester}

There are two schools of thought regarding the most likely time for sensitization to occur. The first school believes that antibody formation occurs mainly after delivery. This belief is a result of observations such as those of Woodrow et al. (1965), who found that women with a large number of foetal cells in the peripheral blood at delivery, indicating a large transplacental haemorrhage, had a higher risk of subsequent antibody formation than those in whom few foetal cells were present. Moreover, it was found that transplacental haemorrhages of sufficient magnitude to stimulate antibody formation were most likely to occur at delivery.

The other school believes that sensitization need not only occur after delivery. Zipursky, Pollock, Neelands, Chown, and Israels (1963) showed that foetal erythrocytes in the maternal blood were often found during pregnancy, and contrary to the findings of Woodrow et al., Zipursky (personal communication, 1967) reported that labour and delivery appeared to play an insignificant part in the production of foetal maternal haemorrhages. He also indicated that these foetal maternal haemorrhages need not be large to cause sensitization. In experiments using Rh-negative male volunteers Zipursky, Pollock, Chown, and Israels (1965) observed that repeated injections of as little as $0.1 \mathrm{ml}$. of $\mathrm{Rh}$-positive cells (similar in amounts to the foetal cells found in maternal blood during pregnancy) could cause anti-D formation. In addition, Zipursky and Israels (1967) and Cohen and Zuelzer (1964) found that most of the sensitization present after delivery occurred in women who had few, if any, foetal erythrocytes in the blood at term. These findings suggested that transplacental haemorrhages and the subsequent risk of sensitization may occur at any time during pregnancy, not only at delivery. Our experience supports the latter view and indicates that there is a definite risk of antibody formation during the last trimester of pregnancy.

Mollison (1968) has stated " an Rh-negative woman who has a first pregnancy with an ABO-compatible Rh-positive infant has about an $8 \%$ chance of forming detectable anti-Rh by the end of six months after delivery." Although our experience is based on relatively small numbers, it appears that she has a $6 \%$ chance of forming detectable antibodies by the time of delivery of her first child and that this risk of sensitization occurring during pregnancy may be relatively constant in subsequent pregnancies.

\section{Effect of Treatment with $\mathbf{R h}$-immune Globulin}

(a) Subjects with Antibody at Delivery.-Thirteen subjects with evidence of early sensitization at delivery were treated. Only one had detectable anti-D at six months. Nine were untreated (Table VI). Five had detectable antibodies at six months. This difference is significant $(P=0.02)$ and indicates that if anti-D is given in an adequate dose and soon enough after sensitization occurs, further antibody formation can be suppressed.

Finkelstein and Uhr (1964), working with guinea-pigs, found that the first antibody produced in response to an antigen was a gamma-M gammaglobulin, and that it was followed in three to four days by the production of gamma-G globulin. If gamma-G gammaglobulin which contained antibody specific for the antigen was given after the onset of gamma-M production, but before gamma-G antibody was detectable, then further antibody response was suppressed. If, however, the injection was given after gamma-G was detectable it was ineffective in suppressing further antibody production. Wigzell (1966) has gone a step further and has shown that passively administered antibody, given as late as 20 days after a primary stimulus, could still inhibit the production of gamma-G antibody. On this evidence it is interesting to speculate that the antibody found at delivery in the treated subjects who were later negative for anti-D was a gamma-M antibody, and that the $\mathrm{Rh}$-immune globulin was effective because it was given before the onset of gamma-G production. 
There are two possible explanations for the persistence of antibody in spite of treatment in Case 23 (Table IV). Firstly, the stage of gamma-G production may have been reached before the injection was given. Secondly, the $0.5 \mathrm{ml}$. dose of $\mathrm{Rh}$ immune globulin may have been inadequate.

Of interest were the subjects who had evidence of sensitization at delivery, were untreated, and yet became negative for anti-D by six months. If the weak antibody which was found at delivery indicated a primary immune response to the $D$ antigen the subsequent disappearance of the antibody may merely mean that it dropped to a level which was below the sensitivity of our tests. If so, with re-exposure to the $D$ antigen -that is, another $\mathrm{Rh}$-positive foetus, an exaggerated anti-D response typical of a secondary immune reaction may occur. These subjects will be carefully followed in a subsequent pregnancy for evidence of this. In this context, it may be noted that all of the five subjects showing a strong antibody response by the time of delivery (anti-D titre greater than 1:4) were multigravid. These subjects may have been mildly sensitized by a previous pregnancy with a subsequent drop of anti-D to undetectable levels, and during the present pregnancy may have had the exaggerated antibody response to the $D$ antigen typical of a secondary immune reaction.

(b) Subjects with No Detectable Antibody at Delivery.-The largest group in this study was the one in which no antibodies were found at delivery. None of the treated subjects and $4.8 \%$ ( 2 of 42 ) of the untreated subjects subsequently developed anti-D. This $4.8 \%$ incidence of sensitization occurring after delivery is lower than reported in comparable series. We have excluded from this category the individuals who were weakly positive for anti-D at delivery, while other series make no mention of them. If they had been included in our series the overall rate of antibody formation in the untreated subjects would have been $14 \%$ (7 of 51 ).

\section{Antenatal Treatment}

The work of Zipursky and Israels (1967) indicates that giving anti-D gammaglobulin intramuscularly during pregnancy is a safe procedure and that the anti-D given has no detrimental effect on the Rh-positive foetus. With this encouragement, we are now embarking on an antenatal treatment programme.

All Rh-negative women who have $\mathrm{Rh}$-positive husbands and who have no detectable anti-D will be given $0.5 \mathrm{ml}$. $(145 \mu \mathrm{g}$. anti-D) of Rh-immune globulin at 34 weeks' gestation. A further $0.5 \mathrm{ml}$. will be administered on delivery of an ABOcompatible Rh-positive infant. This programme will be compared with more conventional treatment with either 0.5 or $1 \mathrm{ml}$. of $\mathrm{Rh}$-immune globulin given only at delivery.

This study was made possible by grant number 321 from the Department of Public Health of the Province of Alberta and the University of Alberta Hospital.

We acknowledge with thanks the assistance of Mrs. G. Schultz and Dr. A. G. Stewart in the preparation of this manuscript.

\section{REFERENCES}

Brit. med. F., 1966, 2, 907.

Buchanan, D. I. (1956). Amer. F. clin. Path., 26, 21.

Buchanan, D. I., and Dierich, K. P. (1965). Transfusion (Philad.), 5, 11. Canad. med. Ass. F., 1967, 97, 1294.

Chown, B. (1967). Personal communication.

Cohen, F., and Zuelzer, W. W. (1964). Vox Sang. (Basel), 9, 75.

Finkelstein, M. S., and Uhr, J. W. (1964). Science, 146, 67.

Freda, V. J., Gorman, J. G., and Pollack, W. (1966). Science, 151, 828. Mollison, P.' L. (1968). Brit. F. Haemat., 14, 1.

Wigzell, H. (1966). ₹. exp. Med., 124, 953 .

Woodrow, J. C., et al., (1965). Brit. med. f., 1, 279.

Zipursky, A., and Israels, L. G. (1967). Canad. med. Ass. F., 97, 1245. Zipursky, A., Pollock, J., Neelands, P., Chown, B., and Israels, L. G. (1963). Lancet, $2,489$.

Zipursky, A., Pollock, J., Chown, B., and Israels, L. G. (1965). Birth Defects, Original Article Series, 1, 84.

\title{
Investigation into the Attenuation of Influenza Viruses by Serial Passage
}

\author{
A. S. BEARE,* M.B., M.C.PATH. ; M. L. BYNOE,* M.B., B.S.; D. A. J. TYRRELL,* M.D., F.R.C.P., M.C.PATH.
}

\begin{abstract}
Cummary : For vaccination live viruses are better than $\checkmark$ dead ones, but live influenza vaccines are difficult to prepare. One influenza $A_{2}$ and two influenza $B$ viruses were passed in series in embryonated eggs. At several stages of their passage they were inoculated into volunteers, and their effects assessed by virus isolations, antibody rises, and clinical reactions. The $A_{2}$ virus and one of the influenza $B$ viruses, both of which had grown readily in embryonated eggs on first isolation, continued to induce human infections and clinical reactions after 30 egg passes. The other influenza $B$ virus acquired enhanced human pathogenicity after three passages from man to man. After adaptation to eggs in which it at first grew reluctantly, its human virulence was appreciably reduced. It underwent no further change during a total of $20 \mathrm{egg}$ passes. There was little convincing evidence of an increased incidence of clinical reactions during the winter seasons, but the numbers of volunteers were too small to draw definite conclusions.
\end{abstract}

* Common Cold Research Unit, Salisbury, Wiltshire.

\section{Introduction}

The use of living influenza viruses as vaccines has many advantages. The vaccines are quickly and painlessly administered as drops or spray and induce a high degree of immunity (Beare et al., 1968). However, many problems arise in their preparation. In our hands the Russian $A_{2}$ virus Iksha failed to infect after a few passes in the laboratory, and this was attributed to the effects of egg passage (Zhdanov et al., 1957; Beare et al., 1967). Burnet and Bull (1943) originally suggested that influenza viruses were inherently genetically unstable and that it might be possible to attenuate them by egg passage so that they could be used as living vaccines. This has now been said in more precise terms by Zhdanov (1967), who maintains that passage in embryonated eggs induces first a rapid loss of human pathogenicity and later a loss of human infectivity. He adds that the number of passes needed for these changes varies rather widely with different virus strains, and that the changes themselves can be detected only in volunteer trials, since there are no reliable laboratory markers by which they can be predicted. Our own subsequent experience with influenza B viruses, however, indicated that these were 